\title{
CHANGES IN THE FENUGREEK (TRIGONELLA FOENUM-GRAECUM L.) YIELD ON THE EFFECT OF DIFFERENT DOSE FERTILIZER TREATMENTS
}

\author{
Viktor József Vojnich ", Judit Petö, András Palkovics, Attila Hüvely \\ Department of Agricultural Sciences, Faculty of Horticulture and Rural Development, John von Neumann \\ University, Hungary \\ https://doi.org/10.47833/2020.1.AGR.010
}

Keywords:
yield
open-field
magnesium treatments
fertilizer
Fenugreek (Trigonella foenum-
graecum L.)

Article history:

Received 10 Nov 2019

Revised 25 Nov 2019

Accepted 29 Nov 2019

\begin{abstract}
Fenugreek (Trigonella foenum-graecum L.) belonging to the legumes (Fabaceae) family is an annual plant. The plant is of Mediterranean origin, native to the Mediterranean coast. It is a multi-use plant that is used as a herb, spice and fodder plant. Fenugreek has high protein content and is well suited for feeding domestic and wild animals. Our open-field experiment was set up at the beginning of April 2018 in the John von Neumann University, Faculty of Horticulture and Rural Development, Kecskemét, Hungary. The aim of the fertilizer treatments was to show how nutritional values of the stem and leaves are changing. The treatments were: Treatment $1=150 \mathrm{~kg} \mathrm{Ha}^{-1}$, Treatment $2=$ $300 \mathrm{~kg} \mathrm{Ha}^{-1}$, Treatment $3=450 \mathrm{~kg} \mathrm{Ha}^{-1}$ complex fertilizer. The treatments were carried out in plots of 50-50 $\mathrm{m}^{2}$. In the experiment, different nutrient supply treatments were set up to achieve the highest fresh biomass weight. The fertilizer used in the research was Novatec premium (15 N - $3 \mathrm{P}_{2} \mathrm{O}_{5}-20 \mathrm{~K}_{2} \mathrm{O}-2$ $\mathrm{MgO})$. When measuring fresh weight of fenugreek, the highest value was measured after $300 \mathrm{~kg} \mathrm{Ha}^{-1}$ treatment $(14.45 \mathrm{~kg})$. The values of treatment $1(7.8 \mathrm{~kg})$ and treatment $3(8.5 \mathrm{~kg})$ were almost the same. The highest dose of treatment $\left(450 \mathrm{~kg} \mathrm{Ha}^{-1}\right)$ resulted a decrease in the yield of $T$. foenum-graecum in our experiment.
\end{abstract}

\section{Introduction}

Trigonella foenum-graecum $\mathrm{L}$. is an annual plant belonging to the Fabaceae family of legumes (Fabales) [1]. Its leaves are like those of alfalfa, the leaves are scattered along the stem [2]. The plant is primarily self-pollinating, but can also be cross-pollinating [3]. The plant is of Mediterranean origin, native to the Mediterranean coast. In temperate countries, it is grown as a spring-sown plant. It is grown as a winter-sown plant in Egypt, Morocco and India [4]. In Hungary, Sámuel Diószegi and Mihály Fazekas published in the Hungarian Phenomenon in 1807 as a wild herb [5]. In Hungary, before 1945, fenugreek was cultivated in the southern part of the country, as a horticultural crops. Later, in 1969-1970, the Tápiószelei Agrobotany Institute started the experimental cultivation. From 1982, research on the technology of cultivating fenugreek and the production of new, intensive varieties began in Mosonmagyaróvár. Then, in 1987, a new Hungarian fenugreek breed has been generated, known under the name "Óvári-4". This variety was registered later, in 1994. It is currently cultivated in 100 hectares in Hungary.

\footnotetext{
* Corresponding author. Tel.: +36 76517623

E-mail address: vojnich.viktor@kvk.uni-neumann.hu
} 
The word foenum-graecum means "Greek hay" because the ancient Greeks used the plant to feed animals [6]. The Egyptians and Romans, also called it by this name. Its medical value is also mentioned by Ebers papyrus, B.C. II. Millenium, used as anti-burn medicine [7]. Despite its many healing properties, its human effect was not widespread until the Middle Ages. In modern science it is only now that its advantages are being discovered. It is primarily used in veterinary medicine. It is mainly used to promote digestion, compress inflammation, fattening and milk selection. In North America, the settlers took fenugreek and used as fodder plant. The T. foenum-graecum crop has several advantages. Rhisobium meliloti is a nitrogen-binding bacterium on its roots that can bind about $70-90 \mathrm{~kg} / \mathrm{ha}$ of nitrogen in the soil [4]. Due to its high protein content, fenugreek is well suited for feeding domestic and wild animals.

It is grown for feed purposes in the following countries: United States, Spain, Algeria, Tunisia, Egypt, Ethiopia, Afghanistan, Iran, India and China [8]. It is used as a green manure plant in the USA (California State), Chile and South France. Using as herbal medicine, it is grown in Central Europe. Fenugreek is grown about 60,000 hectares yearly in the world (located in the major part of India, Pakistan, China), with an average yield of 37 thousand tons per hectare.

In our experiment, different fertilization treatments were set to reach the highest volume of green mass and to follow the most advisable treatment dose under these circumstances.

\section{Material and methods}

The experiment was carried out in the pilot farm of the John von Neumann University, Faculty of Horticulture and Rural Development, in Kecskemét, Hungary in 2018. Our test plant was fenugreek (Trigonella foenum-graecum L.). In the course of the open field trials, different nutrient doses were applied. Seed sowing were placed in open field on $9^{\text {th }}$ of April 2018. The treatments were carried out in plots 50-50 m², according to the following methods: treatment $1=150 \mathrm{~kg} \mathrm{Ha}^{-1}$; treatment $2=300 \mathrm{~kg} \mathrm{Ha}^{-1}$; treatment $3=450 \mathrm{~kg} \mathrm{Ha}^{-1}$ complex base fertilizer. Mechanical weed control was applied. No chemicals or herbicides were applied. The harvest took place from June $25^{\text {th }}$ to July $9^{\text {th }}$.

The soil analysis of the experimental area (Table 1) and its evaluation was carried out by Soil and Plant Testing Laboratory of Faculty of Horticulture and Rural Development (Kecskemét).

Table 1. Soil characteristics of the experimental area (2018)

\begin{tabular}{|c|c|c|}
\hline Denomination & Measurement unit & Value \\
\hline $\mathrm{pH}_{\mathrm{kCL}}$ & - & 7.61 \\
\hline $\mathrm{K}_{\mathrm{A}}$ & - & 28 \\
\hline Water soluble salt & $\mathrm{m} / \mathrm{m} \%$ & $<0.02$ \\
\hline $\mathrm{Humus}$ & $\mathrm{m} / \mathrm{m} \%$ & 1.43 \\
\hline $\mathrm{CaCO}_{3}$ & $\mathrm{~m} / \mathrm{m} \%$ & 2.62 \\
\hline $\mathrm{NO}_{2}-\mathrm{NO}_{3}-\mathrm{N}$ & $\mathrm{mg} / \mathrm{kg}$ & 1.43 \\
\hline $\mathrm{P}_{2} \mathrm{O}_{5}$ & $\mathrm{mg} / \mathrm{kg}$ & 548 \\
\hline $\mathrm{K}_{2} \mathrm{O}$ & $\mathrm{mg} / \mathrm{kg}$ & 104 \\
\hline $\mathrm{Mg}$ & $\mathrm{mg} / \mathrm{kg}$ & 106 \\
\hline $\mathrm{Na}$ & $\mathrm{mg} / \mathrm{kg}$ & 6.61 \\
\hline $\mathrm{Cu}$ & $\mathrm{mg} / \mathrm{kg}$ & 13.1 \\
\hline $\mathrm{Mn}$ & $\mathrm{mg} / \mathrm{kg}$ & 55 \\
\hline $\mathrm{Zn}$ & $\mathrm{mg} / \mathrm{kg}$ & 9.72 \\
\hline $\mathrm{Fe}$ & $\mathrm{mg} / \mathrm{kg}$ & 64.1 \\
\hline $\mathrm{SO}$ & $\mathrm{mg} / \mathrm{kg}$ & 8.4 \\
\hline
\end{tabular}

The fertilizer used in the research was NovaTec premium 15-3-20 $(+2 \mathrm{MgO}+10 \mathrm{~S})+\mathrm{TE}$. Technical data of the fertilizer: $15.0 \%$ total nitrogen $(\mathrm{N}) ; 8.0 \%$ ammoniacal nitrogen $\left(\mathrm{NH}_{4}-\mathrm{N}\right) ; 7.0 \%$ nitrate nitrogen $\left(\mathrm{NO}_{3}-\mathrm{N}\right) ; 0.0 \%$ carbamide nitrogen $\left(\mathrm{NH}_{2}-\mathrm{N}\right) ; 3.0 \%$ phosphate $\left(\mathrm{P}_{2} \mathrm{O}_{5}\right)$ soluble in 
neutral ammonium citrate and water; $2.4 \%$ phosphate $\left(\mathrm{P}_{2} \mathrm{O}_{5}\right)$, water soluble; $20.0 \%$ potassium oxide $\left(\mathrm{K}_{2} \mathrm{O}\right)$, water soluble; $2.0 \%$ total magnesium oxide $(\mathrm{MgO}) ; 1.6 \%$ magnesium oxide $(\mathrm{MgO})$, water soluble; $10.0 \%$ total sulphur $(\mathrm{S}) ; 8.0 \%$ sulphur $(\mathrm{S})$, water soluble; $0.02 \%$ total boron $(\mathrm{B}) ; 0.0 \%$ total copper $(\mathrm{Cu}) ; 0.06 \%$ total iron $(\mathrm{Fe}) ; 0.0 \%$ total manganese $(\mathrm{Mn}) ; 0.01 \%$ total zinc $(\mathrm{Zn}) ; 0.8 \%$ nitrification inhibitor 3.4-dimethyl-pyrazole-phosphate (DMPP) related to total of $\mathrm{NH}_{4}-\mathrm{N}_{\text {and }} \mathrm{NH}_{2}-\mathrm{N}$; low in chlorine $(\mathrm{Cl})$.

Physical properties: 1, physical appearance: solid, granulated; 2, colour: purple; 3, bulk density: $1,250 \pm 100 \mathrm{~kg} / \mathrm{m}^{3} ; 4$, granulometry: $90 \%=2-4 \mathrm{~mm} ; 5$, average granule size (d50): $3.2 \pm$ $0.4 \mathrm{~mm} ; 6, \mathrm{pH}$ (1:10 in water): 4.5-5.5 [9].

\section{Results}

Fresh weight and dry weight values of fenugreek are illustrated in Figure 1. The highest value $(14.45 \mathrm{~kg} / \mathrm{plot})$ for the measurement of the fresh weight of $T$. foenum-graecum was $300 \mathrm{~kg} \mathrm{Ha}^{-1}$ treatments. The $150 \mathrm{~kg} \mathrm{Ha}^{-1}$ fertilizer dose (Treatment 1) showed the lowest fresh weight value (7.8 $\mathrm{kg} / \mathrm{plot})$. The highest dose of treatment $\left(450 \mathrm{~kg} \mathrm{Ha}^{-1}\right)$ resulted in a decrease in the amount of fenugreek (fresh and dry weight as well). Dry matter content of the plants has also decreased.

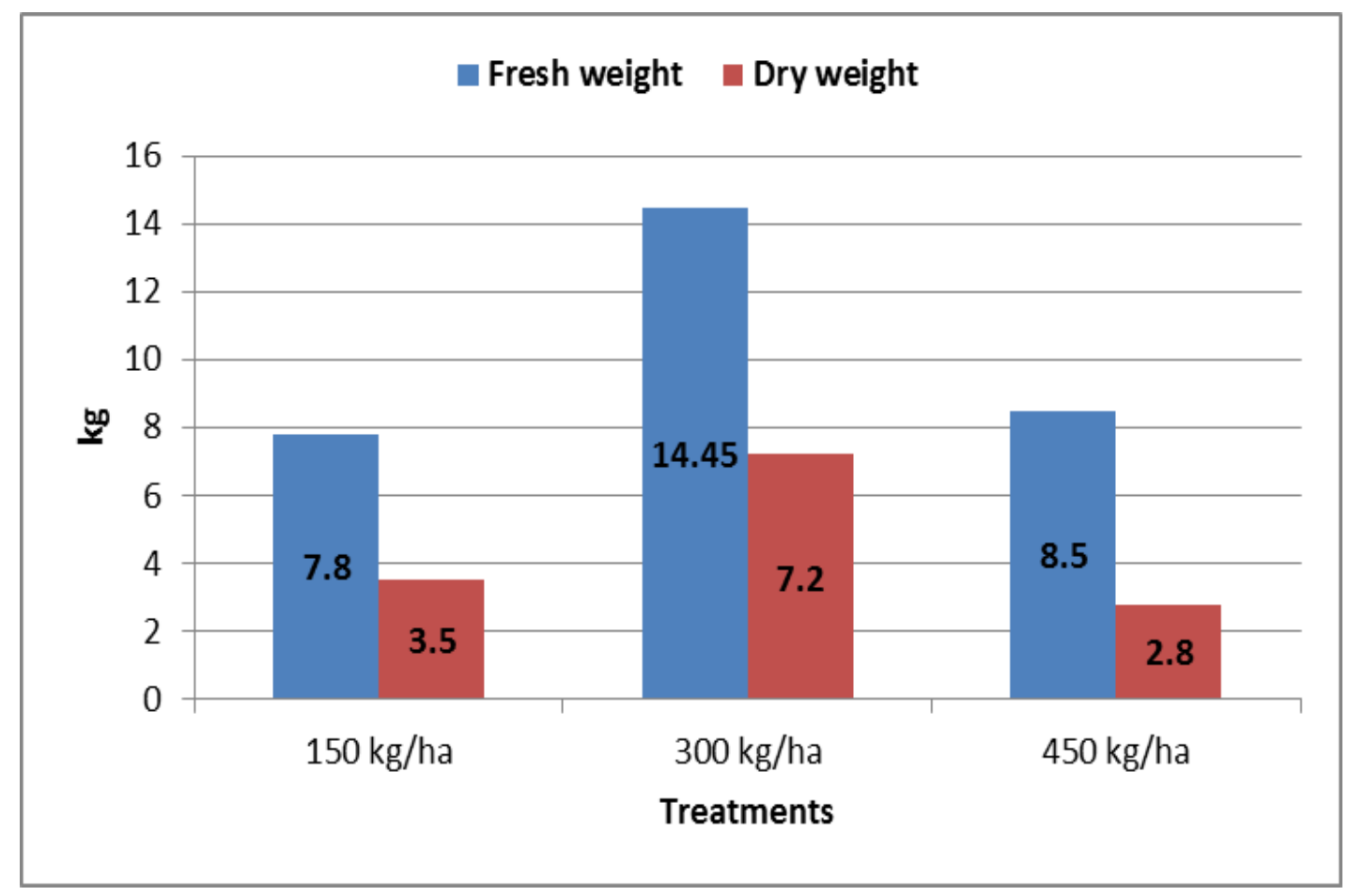

Figure 1. Fresh mass $(\mathrm{kg})$ and dry mass $(\mathrm{kg})$ characteristics of Trigonella foenum-graecum. 


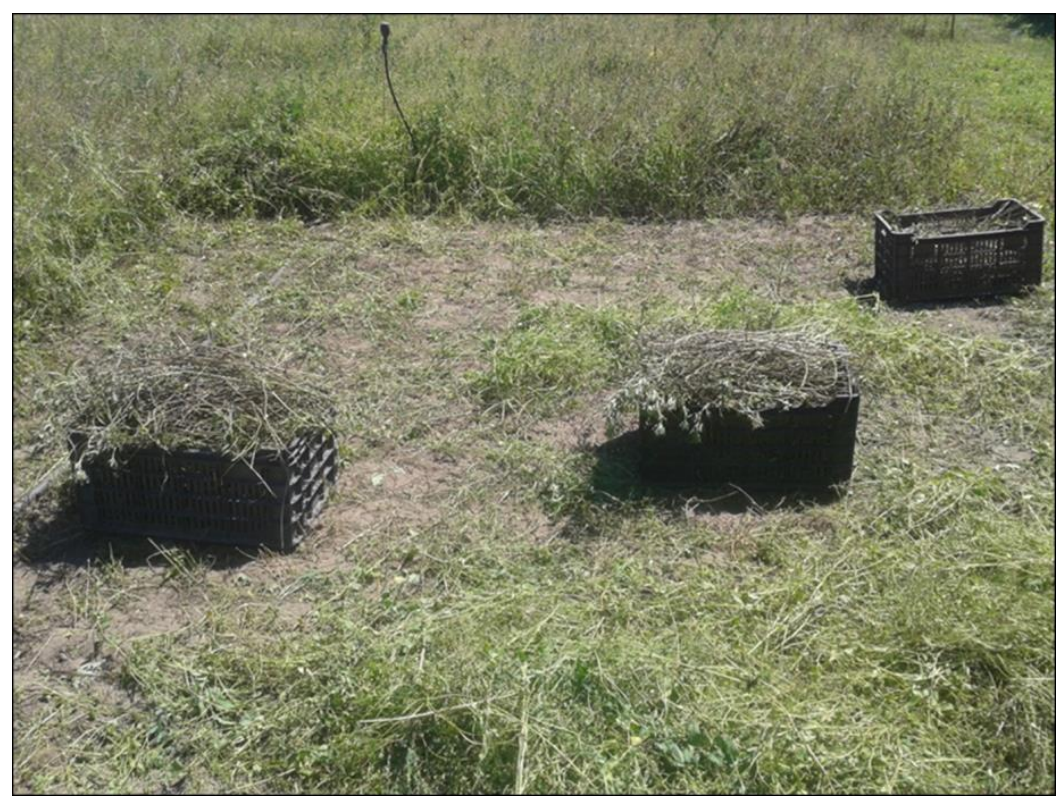

Figure 2. The harvest of fenugreek ( $3^{\text {th }}$ July 2018).

\section{Conclusions}

In the experiment, fenugreek (Trigonella foenum-graecum) was grown as a fodder plant.

The fertilizer used in the research was Novatec premium (15 N - 3 P2O5 - $20 \mathrm{~K} 2 \mathrm{O}-2 \mathrm{MgO}$ ).

The effect of magnesium fertilizer (Novatec premium) we to increase the value by Treatment 2 and decrease the value by Treatment 3 of the Trigonella foenum-graecum yield.

As a result of Treatment $3\left(450 \mathrm{~kg} \mathrm{Ha}^{-1}\right)$, the biomass of fenugreek has decreased (wet and dry weight). In order to interpret the effects, we will continue our investigations in the future.

The highest yield of $T$. foenum-graecum was achieved by Treatment $2\left(300 \mathrm{~kg} \mathrm{Ha}^{-1}\right)$, both in terms of fresh weight $(14.45 \mathrm{~kg})$ and dry weight $(7.2 \mathrm{~kg})$.

Our results suggest that the highest fertilizer treatment resulted in general lower nutrient levels in fenugreek biomass. In our study, $300 \mathrm{~kg} \mathrm{Ha}^{-1}$ fertilizer dose had beneficial effects on biomass production and nutrient contents as well.

In the future, we would like to try other fertilizer treatments during the cultivation of fenugreek.

\section{Acknowledgment}

We thank the support of research that "development of functional, healthy and safe food product chain model based on the principle table, thematic research networks from the field," the EFOP-3.6.2-16-2017-00012 realized under the project of the John von Neumann University.

\section{References}

[1] PROVOROV, H.A. (1985): Izomencsivoszty rasztenij nazsitnyika grecseszkovo (Trigonella foenum-graecum L.) po szpaszbnosztyik szimbiozusz klubenkovümi bakterijami lucernü Buluten vszecajuznovo naucsnoIsszledovatyelszkovo Insztiuta Szelszkohozjajszvennoj Mikrobiologii. 41:21-213.

[2] VAN WYK, B.E. (2005): Handbuch der Nahrungspflanzen. Wissenschaftliche. Verlagsgesellschaft, Stuttgart. pp. 15, 367.

[3] SALVATORE, D.G. (1951): Ricerhe sui consumi idrici e indogini sull autofertilita del feno greco stazione. Agraria Sperimentale, Bari. pp. 1272-1286.

[4] MAKAI S., PÉCSI, S., KAJDI, F. (1996): A görögszéna (Trigonella foenum-graecum L.) termesztése és hasznosítása. Környezet- és Tájgazdálkodási Füzetek. 1996, Vol. 4. pp. 32-35. 
[5] MAKAI, P.S., MAKAI, S. (2004): Görögszéna (Trigonella foenum-graecum L.) fajták terméseredményeinek összehasonlítása és az optimális csíraszám meghatározása. Acta Agronomica Óvariensis, 46(1):17-23.

[6] MÁTHÉ, I. (1975): A görögszéna. Magyarország Kultúrflórája. Akadémiai Kiadó, Budapest. 2:5-50.

[7] VARGA, R., BERÉNYI, B. (2001): A görögszéna (Trigonella foenum-graecum L.) termelésének jelentősége. Diplomamunka, Gödöllö.

[8] KALMÁR, É.A., MAKAI, S. (1999): A görögszéna (Trigonella foenum-graecum L.) beltartalmi értékének és silózhatóságának vizsgálata. Diplomamunka, Mosonmagyaróvár.

[9] http://www.compo-expert.com 